\title{
Energy-Saving and Control of General Indoor Lighting Elements Fed from a Micro-Controlled Hybrid Power Generation System
}

\author{
Yüksel 0ğuz ${ }^{1 *}$, Bahtiyar Dursun², Halil Harun 0̆guz ${ }^{3}$ \\ ${ }^{1}$ Electrical-Electronics Engineering Department, Technology Faculty, Afyon Kocatepe University, Afyon, Turkey \\ ${ }^{2}$ Energy Systems Engineering Department, Technology Faculty, Kirklareli University, Kirklareli, Turkey \\ ${ }^{3}$ Hopa Vocational School, Artvin Çoruh University, Artvin, Turkey \\ Email: *yukseloguz03@gmail.com
}

Received 28 January 2015; accepted 30 March 2015; published 2 April 2015

Copyright (C) 2015 by authors and Scientific Research Publishing Inc.

This work is licensed under the Creative Commons Attribution International License (CC BY). http://creativecommons.org/licenses/by/4.0/

(c) (i) Open Access

\begin{abstract}
In this study, an off grid wind-solar hybrid power generation system was established at Afyon Kocatepe University to meet the energy need of lighting system of three different laboratories. It is planned to efficiently use the energy obtained from the designed hybrid power generation system. For this purpose, PIC 16F877 was used in controlling of lighting load of laboratories. The off-grid wind-solar hybrid power generation system consists of $570 \mathrm{~W} 24 \mathrm{~V}$ mono crystal solar panels, 600 $W$ wind power generation system and accumulator groups. The load control circuit made with PIC 16F877 is designed in a manner that will control the lighting armature groups individually activate and deactivate the armature groups according to intensity of illumination in environment. Besides, separately from generation and storing units constituting the hybrid power generation system, data in $\mathrm{kWh}$ are recorded by means of software in 10 seconds intervals. With the obtained power generation and storing data, analyzing of power consumption data when the load control system in active or passive position is made. According to analysis results, with controlling of lighting load and using of energy obtained from off grid wind-solar hybrid power generation system, $20.6 \%$ energy saving has been ensured.
\end{abstract}

\section{Keywords}

Energy-Saving, Hybrid Power System, Interior Lighting Control, Off-Grid

\footnotetext{
${ }^{*}$ Corresponding author.
}

How to cite this paper: Oğuz, Y., Dursun, B. and Oğuz, H.H. (2015) Energy-Saving and Control of General Indoor Lighting Elements Fed from a Micro-Controlled Hybrid Power Generation System. Energy and Power Engineering, 7, 110-126. 


\section{Introduction}

Energy is an essential source for sustainability of economical developments of countries. Energy demand increases every passing day because of reasons such as economic development, industrialization, urbanization, welfare, increase in population and technological advance. Increase in energy demand obliges orientation towards low cost and safe energy supply policies. As a matter of fact, today, energy policies have become one of the important factors in international competition. Economic growth of Turkey in 2000's has also increased the energy demand and it is predicted that this increase will demonstrate an ongoing tendency [1]. In the world, fossil fuels are being used extensively in many fields, mainly in electric generation, industry, heating, transportation, etc. Today, $\mathrm{CO}_{2}$ rate emitted to atmosphere as a result of burning of fossil fuels has reached to hazardous magnitudes [2].

Besides, fossil fuels and their derivatives on earth show shortening tendency. Fossil fuel based sources almost finished. Dependency on such sources must be decreased both because of $\mathrm{CO}_{2}$ rates in hazardous magnitudes and shortening of fuel sources. This can be managed by using of renewable energy sources. Today, one of the much intensively used renewable energy sources is small powered hydro, wind and solar energy sources. After energy generation is realized by using these sources, if they are used alone, problems can occur in terms of energy continuity. For this reason, system safety and energy continuity must be ensured with utilization two or more energy sources jointly through installation of hybrid power generation systems [3] [4]. The cost analysis has been realized by taking into consideration the useful energy potential of the region, battery or other conventional energy generation units (diesel, gas) having capacity to continue energy supply and off grid hybrid energy generation systems that are economical and generally in size capable of meeting the demanded power requirement. While designing a hybrid power generation system, it must be taken into consideration with environmental approach and be in conformity to economic, physical, operational and safety strategies [5]. The most important parameter that affects the cost of hybrid power generation system is the system dimensioning. With suitable dimensioning of hybrid power generation system and determination of a suitable control strategy, cost of the system can be minimized [6]. Nowadays, the most commonly used hybrid power generation system is the windsolar hybrid system. In the literature, there are many studies made related to hybrid power generation systems. Most of the studies on hybrid power generation systems contain regional studies. In İzmir, applicability of battery aided solar-wind hybrid energy system was researched. In this study, a sample house of which daily average consumption was $12.1 \mathrm{kWh}$ and highest consumption per hour was $3.7 \mathrm{kWh}$ was accepted as an autonomous load and HOMER software was used for dimensioning of system. The system was dimensioned depending on wind speed, solar radiation and temperature data and its sensitivity analysis was made [7]. Köse (2010) theoretically examined energy generation from off grid and on grid hybrid energy systems consisted of wind and solar within the Kütahya Dumlupınar university Center Campus area. Similarly, Dursun et al., studied a local micro-grid wind-PV hybrid system for a remote community with 50 houses in Edirne in order to determine the optimal configuration and also make a techno-economical analysis for the considered power generating systems by the HOMER software which was used in constructing and designing the power generating systems. Furthermore, fuel savings and reduction in carbon emissions of different hybrid systems are investigated [8]. Moreover, the energy demand of a house in Gebze-Turkey, was met using wind energy as a primary energy source combined with rechargeable batteries are presented by Dursun and Gokcol. The wind turbine generators considered were of various nominal powers, ranging from 0.6 to $450 \mathrm{~kW}$. For each wind turbine, the necessary number of batteries to continuously supply the house with energy was calculated and an economic analysis of each system was performed [9].

Dimensioning of the hybrid energy generation system was made according to the results obtained from data analysis of wind and solar energy potential in the region and total sixteen different scenarios-ten off grid between 1 - $10 \mathrm{~kW}$ and six on grid between 15 - $45 \mathrm{~kW}$ were established [10]. Muralikrishna and his colleagues made studies on decreasing of energy storing requirements of hybrid energy generation systems. For this purpose, a Simulink model of solar panel system alone, wind turbine system alone and solar-wind hybrid power generation system was prepared, lifecycle cost for economic evaluation of hybrid system was established and comparative cost analysis of energy sources was examined in detail [11]. In another study related to dimensioning of hybrid power generation systems, a method for application and characteristics of hybrid solar-wind generation system was developed. Experimental studies helped confirmation of area application possibility of developed model and examination of operating performance and characteristics. With integration of new concept 
and technologies, optimization method of hybrid solar-wind power generation system was developed according to new concepts and lower power source supply possibility in energy cost calculations. With application of optimization model of hybrid solar-wind generation system, dimensioning in technical and economic aspects was realized according to system safety requirements [12]. In a study made by Gabriele Seeling-Hochmuth, different from the study of (Lu, 2004), dimensioning of hybrid power generation systems and optimization of operating control was realized. In this study, for operating control and dimensioning of hybrid power generation systems, a new approach was developed for purpose of minimizing the cost per kWh. The new approach was developed with using of algorithm and slope calculations were not needed [13].

Lighting load has an important share in energy consumption. In literature, there are some studies about energy saving in lighting systems and effective using of energy consumed for purpose of lightening. Gençoğlu, in his study, compared light sources used in interior lighting, researched reasons of energy loss in lighting and examined remote control systems in interior lighting. Besides, economical methods and economic measures were determined for purpose of achieving saving from lighting energy [14]. In another study made on controlling of lighting systems, lamps of which type and position had been determined with computer and lighting program were gradually controlled by means of PLC. Turn on-off positions of lamps were determined according to change of daylight. Consequently, conventional (manual) controlled lighting system and automation system in this study was compared and it was determined that saving was achieved [15]. In another study, a new lighting system was installed to an east-fronted laboratory with high efficient fluorescent lamps. With a motion sensor placed in the laboratory and circuit that measures light level, input variables of control system were determined. Lightening of laboratory was made gradually with fuzzy logic control system as real-time on computer and it was determined that saving was achieved [16].

In this study, under Afyonkarahisar province climate conditions, electric energy needed for lightening of Electric Laboratory-I and Electric Laboratory-II will be met from battery-aided $1170 \mathrm{~W}$ solar-wind hybrid power generation system.

A control system for lighting load was designed in a manner energy generated from hybrid power generation system that would meet energy need of armature groups for a longer period. The designed load control system will control twelve armature groups individually at the laboratory according to light intensity entering into laboratory medium. PIC 16F877 microprocessor in the load control system, by controlling twelve armature groups independently according to light intensity values taken from lux sensor, will minimize energy consumption of laboratory and ensure the most convenient lighting intensity. So, in consumption of electric energy generated by solar-wind hybrid power generation system, determination of energy saving difference manual controlled lighting system and automatic controlled lighting system is aimed.

\section{Installation and Operation of Off-Grid Wind-PV Hybrid Power System}

$1170 \mathrm{~W}$ solar-wind hybrid power generation system consists of $190 \mathrm{~W}, 3$ numbers of $24 \mathrm{~V}$ mono crystal solar panels and $600 \mathrm{~W}, 3$-phase, permanent-magnet, synchronous generator (PMGS) wind turbines (rotatable $360^{\circ}$ according to direction of wind).

$100 \mathrm{Ah}, 12$ V, 6 numbers of gel deep cycle accumulator groups were installed jointly with hybrid power generation system to store consumption surplus electric energy or ensure continuity of energy in times not generation is made. By regulating electric energy generated in the system with the charge control unit, charging of battery groups is ensured. With energy generated in the system via charge control unit, data are obtained in 10 second intervals and recorded with the aid of computer. Energy generated in the system is inverted to AC power with the aid of $3 \mathrm{~kW}$ full sinus inverter and energy needed by our loads is ensured. General view of battery-aided solarwind hybrid power generation system and its open connection schema are given in Figure 1.

Technical specifications of each component in the hybrid power generation system are given in Table 1 .

When technical data given in Table 1 related to wind turbine are examined, it is understood from the power curve that the wind speed value required for starting of generation of wind turbine is $3 \mathrm{~m} / \mathrm{sec}$ and the wind speed that is called as dangerous wind speed and at which the turbine must be stopped is $25 \mathrm{~m} / \mathrm{sec}$. In Figure 2, power curve of VIND EFS600 wind turbine is seen [17]. Braking process lasts 1 minute and at the end of this period, it is activated again. Besides, when battery voltage of wind turbine becomes $28.2 \mathrm{~V}$, braking process is activated automatically and as soon as battery voltage falls below $28.2 \mathrm{~V}$, if there is sufficient wind, it starts generation again.

Another important component in hybrid power generation system is the charge control unit. Connection schema of the charge control unit is given in Figure 3. Technical specifications of charge control unit are given in Table 1. 


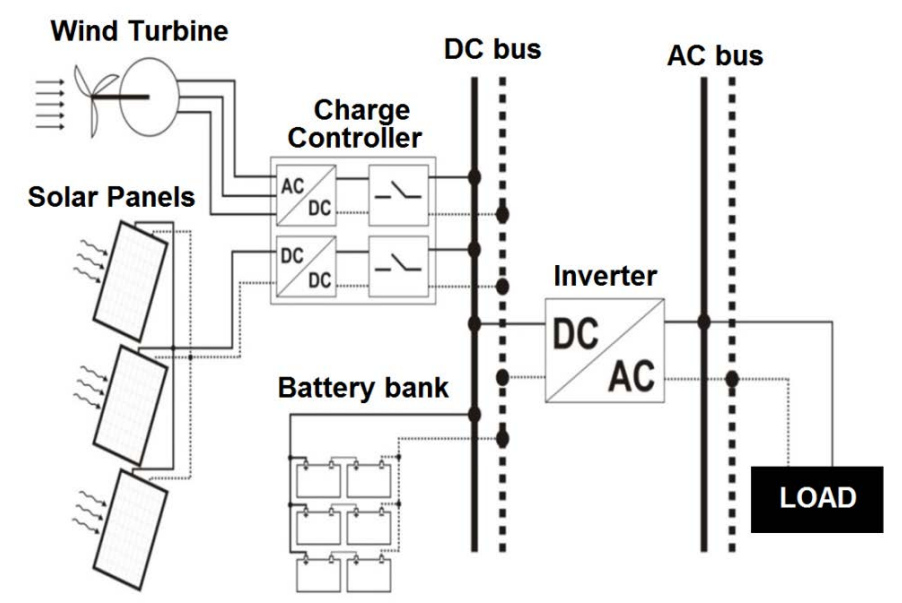

Figure 1. General view and open connection schema of battery-aided wind-solar hybrid power generation system.

Table 1. Technical specification of hybrid system components.

\begin{tabular}{|c|c|c|}
\hline Component names & \multicolumn{2}{|c|}{ Technical specification of components } \\
\hline Wind Turbine & $\begin{array}{l}\text { Output voltage: } 12 / 24 \mathrm{~V} \\
\mathrm{~V}_{\text {cut-in }}=3 \mathrm{~m} / \mathrm{s}\end{array}$ & $\begin{array}{l}\text { ower: } 600 \mathrm{~W} \text { - Max Power: } 750 \mathrm{~W} \\
\text { cut-out }=25 \mathrm{~m} / \mathrm{s}\end{array}$ \\
\hline Solar Panel & $\begin{array}{l}\text { Power: } 190 \mathrm{~W} \\
\text { Efficiency: \%17.75 } \\
\text { Max. Power current: } 5.12 \mathrm{~A} \\
\text { Short circuit current: } 5.54 \mathrm{~A}\end{array}$ & $\begin{array}{l}\text { ype: Monocyrstal } \\
\text { lax. Power voltage: } 37.08 \mathrm{~V} \\
\text { pen voltage circuit: } 44.48 \mathrm{~V} \\
\text { orking temperature scale: } 40^{\circ} \mathrm{C} /+85^{\circ} \mathrm{C}\end{array}$ \\
\hline Charging Controller & \multicolumn{2}{|l|}{$\begin{array}{l}600 \mathrm{~W} \text { RT/ } 600 \mathrm{~W} \text { PV } 24 \mathrm{~V} \text { charge control unit } \\
\text { WT and PV voltage and current monitoring } \\
\text { Instant data transfer in LCD screen }\end{array}$} \\
\hline Battery Bank & Battery capacity: $100 \mathrm{Ah}$ & Type: Gel-type battery \\
\hline Inverter & $\begin{array}{l}\text { Power: } 3 \mathrm{~kW} \\
\text { Efficiency: >85\% }\end{array}$ & $\begin{array}{l}\text { Instantaneous power: } 6 \mathrm{~kW} \\
\text { Type: Full sinus }\end{array}$ \\
\hline Control Box & \multicolumn{2}{|c|}{ It includes battery bank, charge control unit, inverter and other electronic circuit. } \\
\hline LED Armature & $\begin{array}{l}\text { Power: } 40 \mathrm{~W} \\
\text { Input voltage: } 12 \mathrm{~V} \\
\text { Working temperature: }-30^{\circ} \mathrm{C} / 40^{\circ} \mathrm{C}\end{array}$ & $\begin{array}{l}\text { Lumen: } 3000 \mathrm{~lm} \\
\text { Working frequency: } 47 \text { - } 63 \mathrm{HZ} \\
\text { Working efficiency: >90\% }\end{array}$ \\
\hline
\end{tabular}

Additionally, charge control unit is activated at $4 \mathrm{~V}$ because of its low voltage feature. In other words, as soon as the wind turbine reaches to a speed enabling to generate $4 \mathrm{~V}$, unless the voltage value of battery groups is above $28.2 \mathrm{~V}$, it starts generation. This feature enables wind turbine to generate energy even at low wind speeds. Charge control unit has two DC outputs. One of these outputs makes DC output of charge control unit active or passive depending on lighting intensity falling on solar panel. The second output makes DC output of charge control unit active depending on lighting intensity falling on solar panel and makes DC output passive at determined time. This prevents LED armature to consume unnecessary energy used in exterior lighting.

Technical specifications of inverter used to invert DC energy generated by hybrid power generation system to AC energy are given in Table 1. Other than the referred ones in Table 1, when the energy generated by wind-solar hybrid power generation system or stored by battery groups falls below $20 \mathrm{~V}$, inverter passes to low voltage mode and is automatically deactivated. In that case, lamps at the laboratory are supplied via grid by means of automatic control circuit until voltage level of batteries increases above $22 \mathrm{~V}$. When the battery voltage increases above $22 \mathrm{~V}$, contacts of inverter are closed with automatic control circuit and energy need of lamp groups are met via hybrid power generation system. Last situation of the system installed at Afyon Kocatepe University campus is seen in Figure 4. 


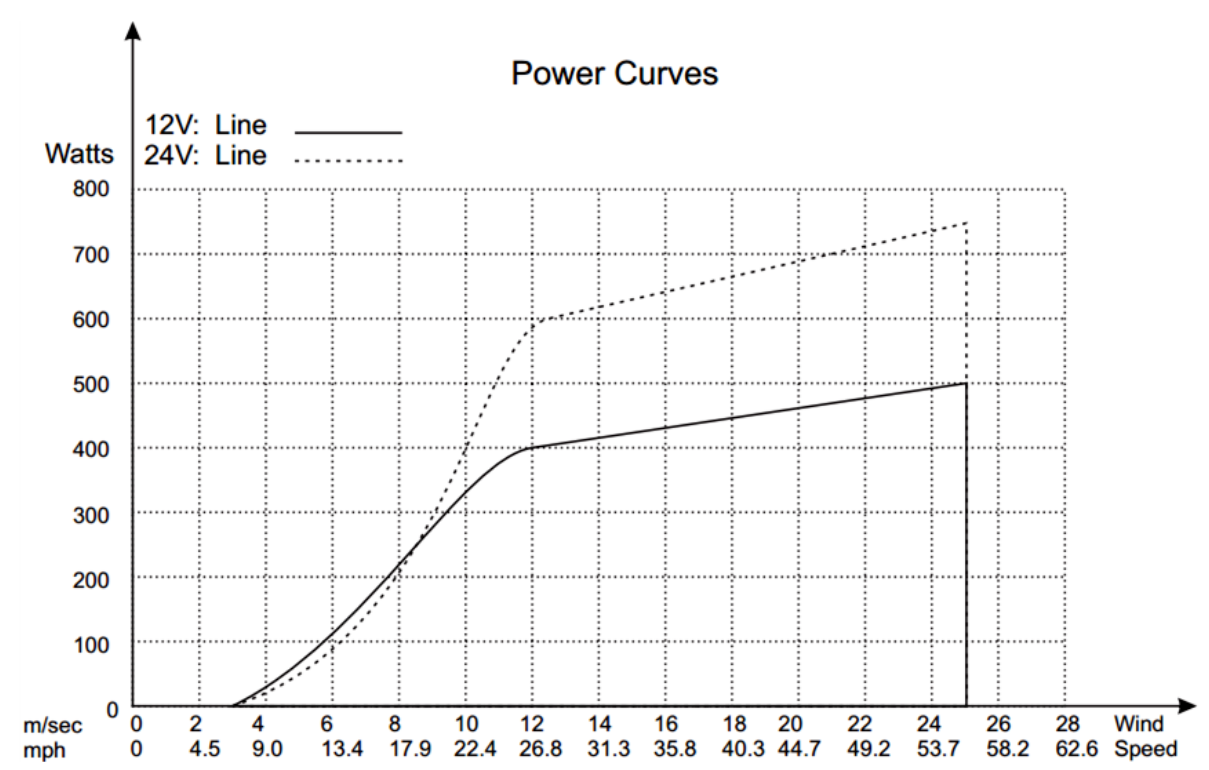

Figure 2. Power curve of VIND EFS600 wind turbine.

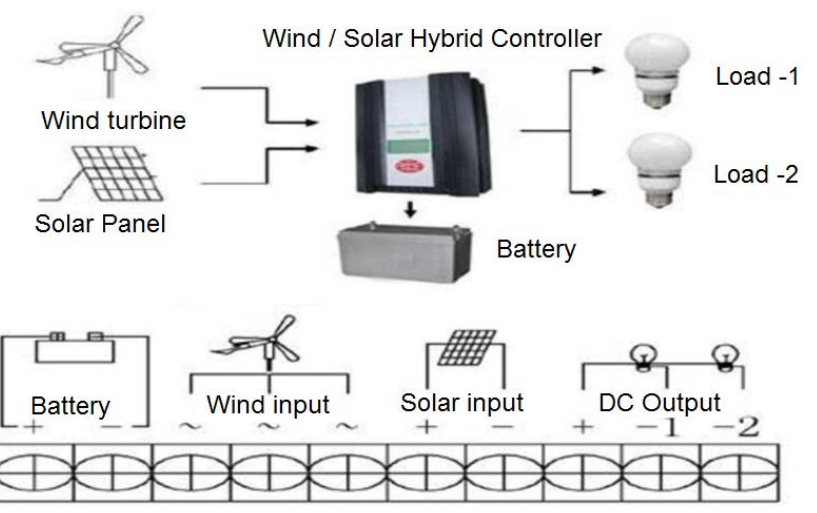

Figure 3. Connection schema of charge control unit.

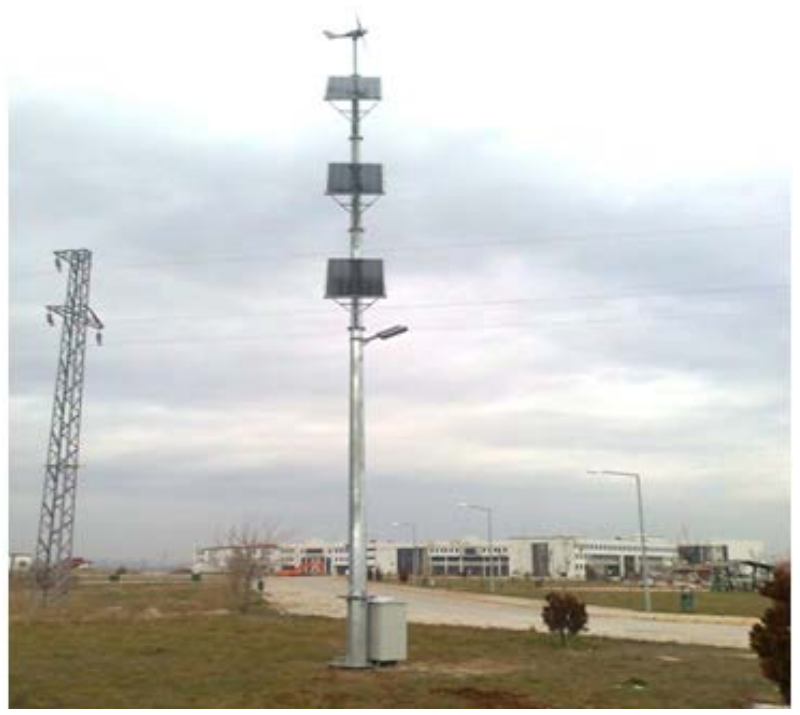

Figure 4. The most recent situation of solar-wind hybrid charge controller system. 


\section{Lighting Control by Using PIC 16F84}

With lighting load control system, it is aimed to control the armature groups in the laboratory. The controlling process to be made is to activate or deactivate armature groups depending on rate of day light coming from outside and to keep lighting intensity of laboratory above 30 lux critical value.

In this way, it is planned to supply armature groups for a longer time with electric energy generated by hybrid power generation system and ensure too much saving in life of fluorescent lamps. In designing of load control system, PIC 16F877 manufactured by Microchip company was preferred. The reason of preference of this microcontroller was that; it has sufficient number of input and output ends and analogue ends. Circuit prepared by using PIC 16F877 microcontroller will control the armature groups in the laboratory according to light intensity coming from outside. General view of lux meter to measure the light intensity coming from outside at that point is given in Figure 5.

Positioning of luxmeter in the laboratory is vitally important. Used sensor has a field of vision effective $30^{\circ}$ around of max sensitiy area in $45^{\circ}$ distance from the floor it is placed. Field of vision of sensor must be concicided with point or points of laboratory where light comes. Images related to positioning of luxmeter in the laboratory are seen in Figure 6.

As 300 lux value has been used as critical value in laboratory lighting, working range of sensor was determined as 300 - 3000. One of the most important features of lux sensor and similar measurement devices is linear change of its operating range. Connection schema of load control system planned to be realized is given in Figure 7 . In the load control connection schema, fuse-1 refers to line from the wind-solar hybrid power generation system and fuse-2 refers to line from the grid. Which of these two electric supply lines will be activated is determined with pako-switch-1. If pako-switch-1 is in 1 mode, armature groups are supplied via hybrid power generation system. If pako-switch-1 is in 2 mode, armature groups are supplied via grid power. Electric line from pake-switch-1 is connected to pako-switch-2 via fuse-3. Fuse-3 between two pako switches are connected for purpose of protection. Pako-switch-2 in the load control system determines the control management of florescent lamps. If pako-switch 2 is taken in 1 mode, armature groups will be controlled manually by means of switches.
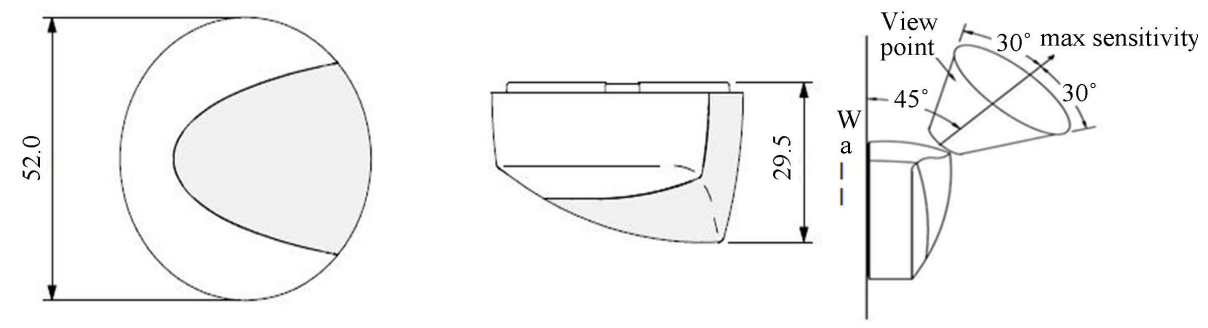

Figure 5. General view of lux sensor and field of vision of lux sensor.

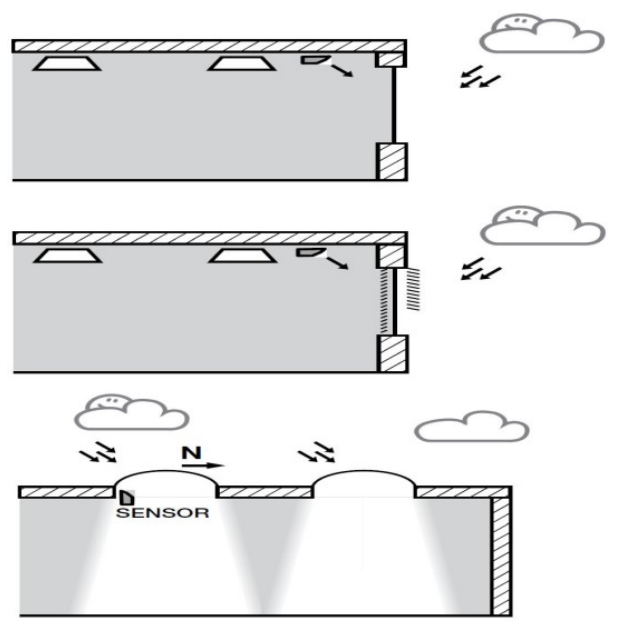

Figure 6. Positioning of lux sensor in the laboratory. 


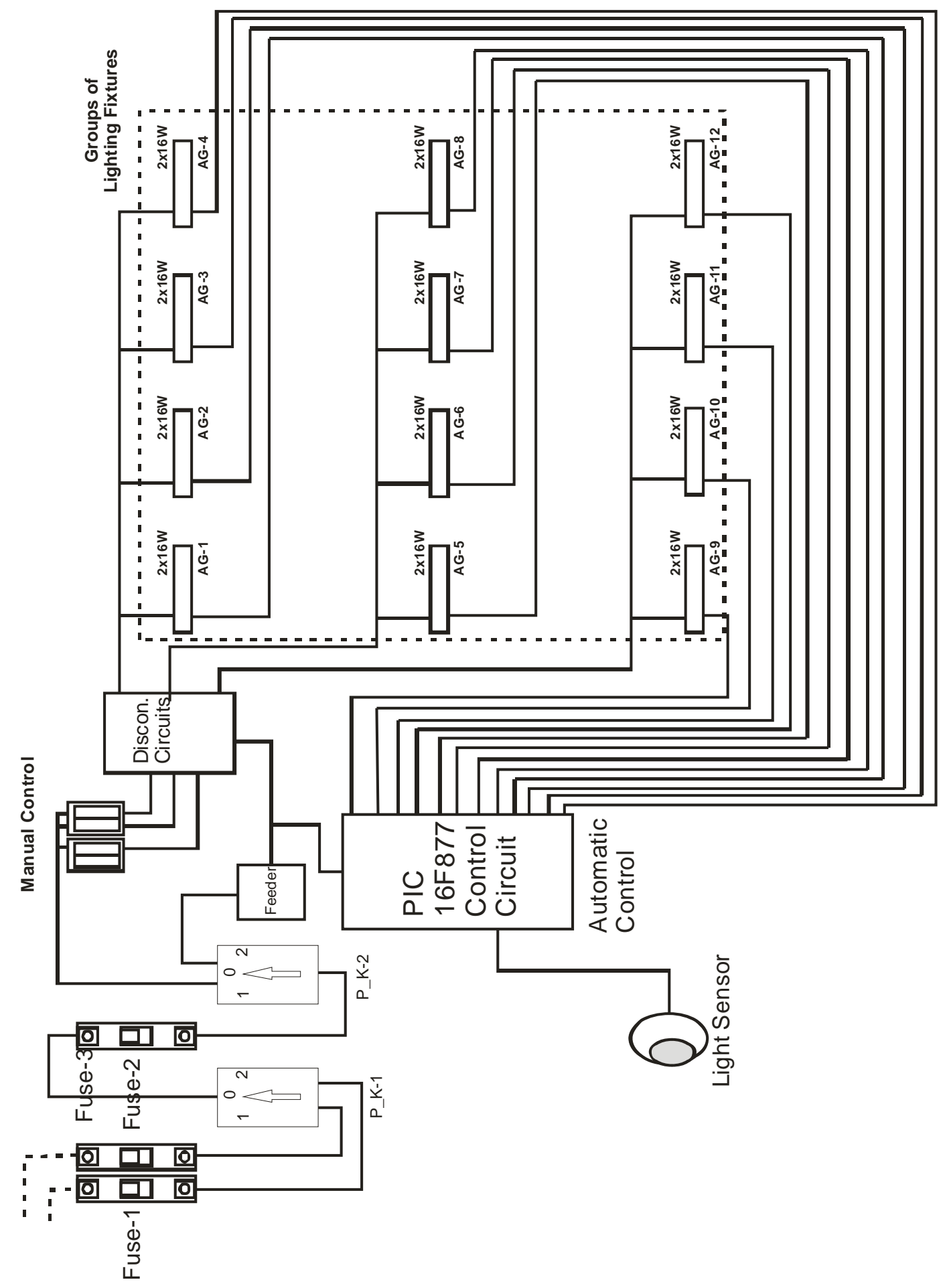

Figure 7. Connection schema of load control system.

If pako-switch 2 is taken in 2 mode, armature groups will be controlled automatically depending on light intensity falling on lux sensor. Operating logic of load control system is as stated above. Important electronic components, used in making of load control circuit, are given below in detail.

Flow diagram showing the operating logic of load control system made with PIC 16F877 is seen in Figure 8. 


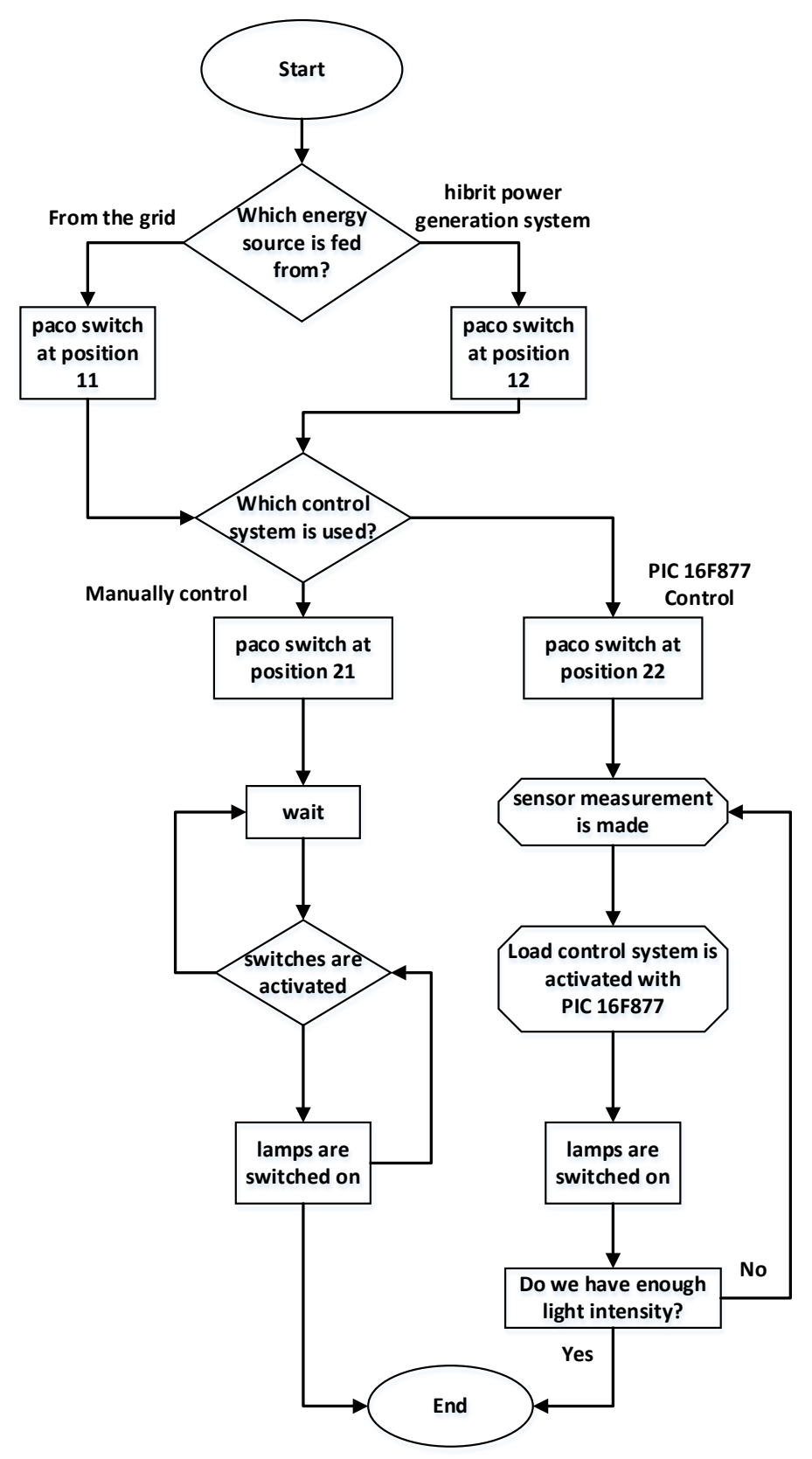

Figure 8. Flow diagram of load control system.

Existing lamps used in lighting of laboratory are controlled manually for quartet armature groups (four in each group). Besides to unnecessary energy consumption that occurs because of this situation, it may also cause work accidents depending on excessive lighting of environment. At this point, high control circuit with PIC was designed to both ensure energy saving with hybrid wind solar power generation system and extend life of equipment and provide human health and safety. The designed circuit may change the number of lighting armature groups depending on day light coming in the laboratory at different hours of days. In this way, it will ensure both energy saving and lighting level of laboratory will be kept at ideal level. At this point, two options in controlling of armatures at the laboratory are presented. One of them is the existing manual control and the second is the automatic control desired to be made via control circuit with PIC. Preference between these two positions is provided with one pako switch. While in automatic control, each armature group is controlled individually, in manual control, control is made via three switches in quartet armature groups. To eliminate problems resulting from this difference 
in controlling of armature groups, four armature groups connected in parallel to each other during manual control of armature groups were disconnected with disconnector circuit during automatic control and so, problem resulting from difference between two controls was eliminated. Printed circuit state of established disconnector circuit is given in Figure 9 below.

The above given disconnector circuit disconnects quartet armature groups in manual control phase as soon as it is passed to automatic control. In this way, while armature groups will be controlled individually in automatic control mode, they will be controlled in quartet armature groups in manual control mode. Besides, as the load control circuit with PIC to be designed will control 12 armature groups at the laboratory in different combinations, first of all, control algorithm of armature groups must be established. For establishment of control algorithm, critical measurement points in the laboratory must be determined and control algorithms must be determined according to these control measurements. In this context, six critical measurement points were determined in the laboratory. Separate measurements were made at the measurement points depending on light intensity coming in the laboratory from outside. These critical measurement points and position of lux sensor that measures light intensity coming from outside are seen in Figure 10.

The critical measurement points given in Figure 10 were determined. Measurements were made at six critical points determined in the laboratory according to light intensity coming from outside and 300 lux value-lower limit for laboratory lighting-was determined as critical point in the measurements. Which armature groups will be passive and which ones will be active were determined according to 300 lux critical value. The control algorithm established according to measurements realized is given in Table 2.

Measurements were made at six critical points determined in the laboratory according to light intensity coming from outside is seen in Table 2 and 300 lux value-lower limit for laboratory lighting-was determined as critical point in the measurements. The determined control algorithm was transformed to programming language understandable by PIC with C programming language. The most recent prepared program was uploaded to PIC 16F877. After the circuit established in ISIS program was transferred to ARES program, its printed circuit was established. Printed circuit schema of the load control circuit that is transferred on plaque and of which component mounting has been made is given in Figure 11.

Besides, printed circuit of circuit to provide supply voltage needed by electronic circuits containing 7805 and 7824 integrates is given in Figure 12.

A 300 Ah accumulator group was established to store electric energy obtained from wind-solar hybrid power generation system. At times there is no energy generation from hybrid power generation system, energy needed for lighting of laboratory will be supplied firstly from accumulators. By considering that accumulator group is completely full and all lamp groups are activated at both laboratories, how long the accumulator group will supply energy the system was found with the calculations given below.

In lighting of a laboratory, 16 W 2 saving lamps and $18 \mathrm{~W} 24$ fluorescent lamps were used. Total power of lamp groups used in lighting of a laboratory is:

Florescent Lamp

$$
\begin{aligned}
P_{F T} & =\text { Number of Lamp } \times \text { Power of Lamp } \\
& =24 \times 18=432 \mathrm{~W}
\end{aligned}
$$
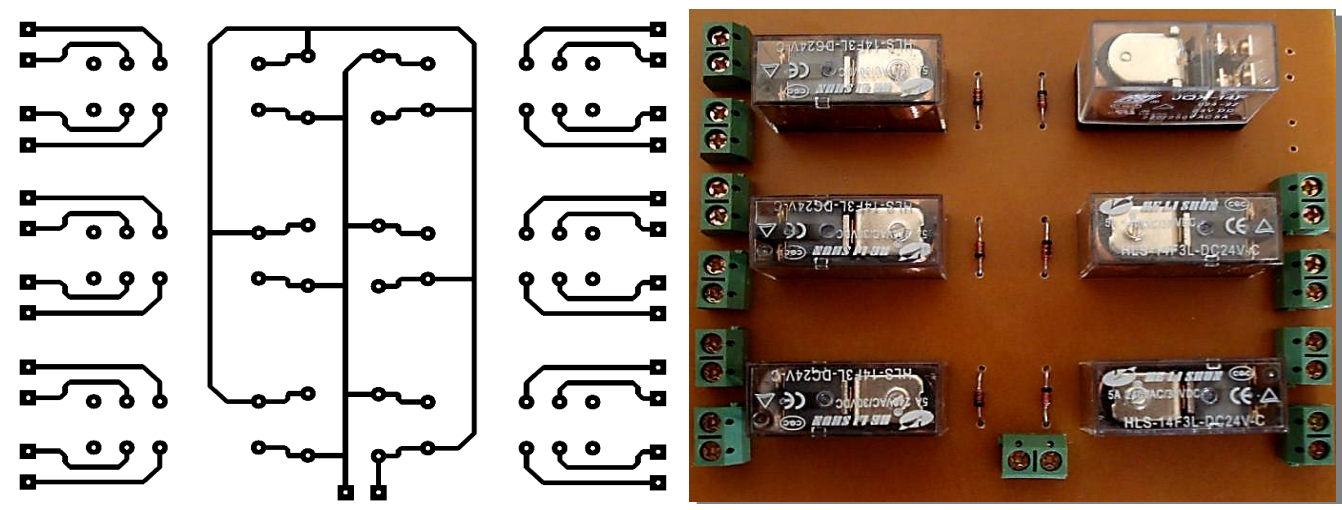

Figure 9. Printed circuit of disconnector circuit and completed situation of component mountings. 


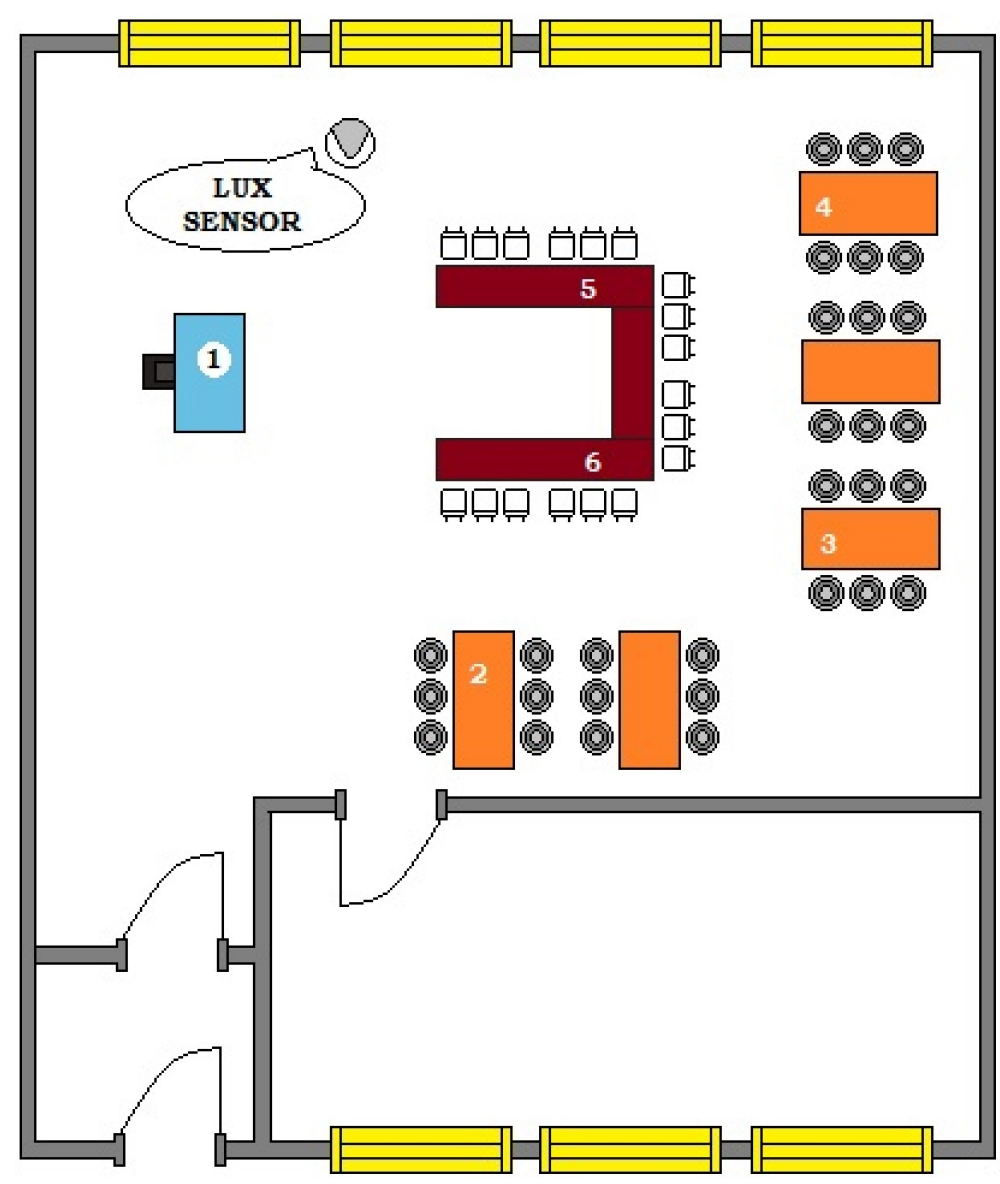

Figure 10. Critical measurement points in the laboratory medium.

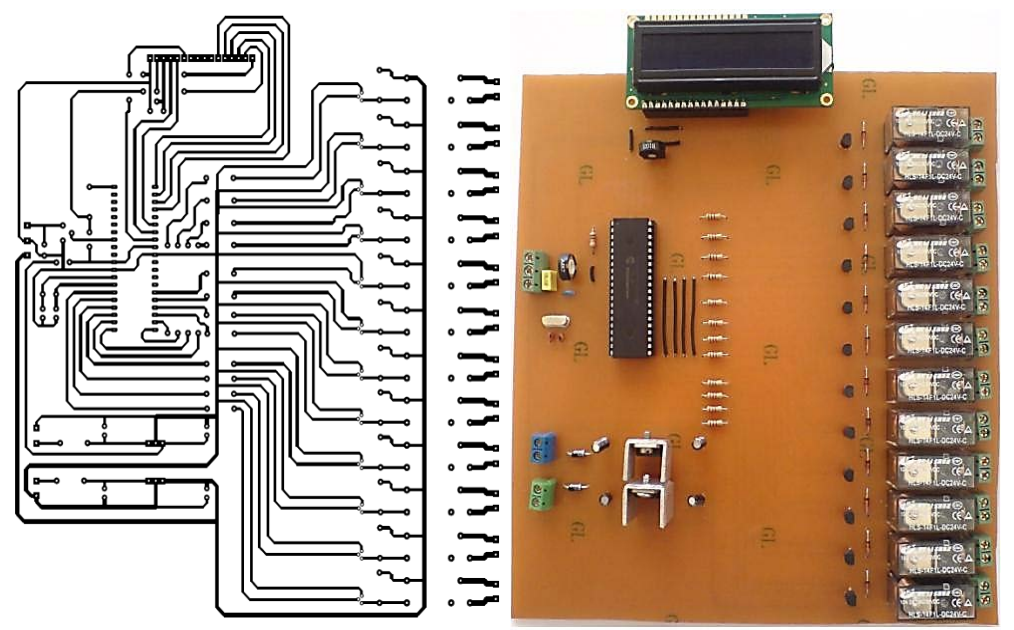

Figure 11. Printed circuit schema of the load control circuit that is transferred on plaque and of which component mounting has been made.

Saving lamp

$$
\begin{aligned}
P_{T T} & =\text { Number of Lamp } \times \text { Power of Lamp } \\
& =2 \times 16=32 \mathrm{Watt}
\end{aligned}
$$

Total power lamp 
Table 2. Control algorithm values of load control circuit with PIC.

\begin{tabular}{|c|c|c|c|c|c|c|c|}
\hline No ${ }^{1}$ & $\begin{array}{l}\text { Light intensity } \\
\text { from outside }\end{array}$ & $\begin{array}{l}\text { Measurement } \\
\text { Point-I }\end{array}$ & $\begin{array}{l}\text { Measurement } \\
\text { Point-II }\end{array}$ & $\begin{array}{l}\text { Measurement } \\
\text { Point-III }\end{array}$ & $\begin{array}{l}\text { Measurement } \\
\text { Point-IV }\end{array}$ & $\begin{array}{l}\text { Measurement Measurement } \\
\text { Point-V Point-VI }\end{array}$ & $\begin{array}{l}\text { Turning on the group } \\
\text { of lighting fixtures }\end{array}$ \\
\hline 1 & 26 & 348 & 348 & 351 & 301 & 333 & $\begin{array}{c}1,2,3,4,5,6,7,8,9,10 \\
11,12\end{array}$ \\
\hline 2 & 58 & 327 & 348 & 356 & 310 & 318 & $1,2,3,5,6,7,9,10,11,12$ \\
\hline 3 & 73 & 321 & 339 & 356 & 348 & 333 & $1,2,3,5,6,7,9,10,11,12$ \\
\hline 4 & 93 & 336 & 339 & 365 & 362 & 345 & $1,2,3,5,6,7,9,10,11,12$ \\
\hline 5 & 105 & 327 & 342 & 327 & 307 & 305 & $2,3,5,6,7,10,11,12$ \\
\hline 6 & 114 & 304 & 348 & 330 & 327 & 305 & $2,3,5,6,7,10,11,12$ \\
\hline 7 & 125 & 310 & 351 & 336 & 339 & 300 & $2,3,5,6,7,10,11,12$ \\
\hline 8 & 134 & 313 & 342 & 336 & 345 & 310 & $2,3,5,6,7,10,11,12$ \\
\hline 9 & 146 & 315 & 351 & 353 & 345 & 310 & $2,3,5,6,7,10,11,12$ \\
\hline 10 & 155 & 327 & 336 & 301 & 336 & 301 & $2,3,5,6,7,10,12$ \\
\hline 11 & 166 & 333 & 356 & 301 & 353 & 304 & $2,3,5,6,7,10,12$ \\
\hline 12 & 175 & 333 & 356 & 307 & 365 & 310 & $2,3,5,6,7,10,12$ \\
\hline 13 & 187 & 301 & 342 & 333 & 383 & 315 & $1,2,5,6,9,10$ \\
\hline 14 & 204 & 305 & 351 & 342 & 435 & 359 & $1,2,5,6,9,10$ \\
\hline 15 & 236 & 310 & 342 & 336 & 482 & 397 & $1,2,5,6,9,10$ \\
\hline 16 & 257 & 310 & 345 & 356 & 520 & 430 & $2,5,6,9,10$ \\
\hline 17 & 304 & 327 & 356 & 342 & 599 & 421 & $2,5,6,9,10$ \\
\hline 18 & 348 & 313 & 315 & 359 & 664 & 544 & $1,5,9,10$ \\
\hline 19 & 374 & 333 & 304 & 359 & 734 & 535 & $1,5,9,10$ \\
\hline 20 & 406 & 353 & 310 & 383 & 801 & 596 & $1,5,9,10$ \\
\hline 21 & 435 & 351 & 304 & 394 & 930 & 620 & $5,9,10$ \\
\hline 22 & 482 & 374 & 318 & 400 & 994 & 678 & $5,9,10$ \\
\hline 23 & 549 & 424 & 336 & 424 & 1146 & 786 & $5,9,10$ \\
\hline 24 & 590 & 453 & 353 & 432 & 1225 & 892 & $5,9,10$ \\
\hline 25 & 657 & 509 & 389 & 292 & 1257 & 959 & 5,9 \\
\hline 26 & 690 & 573 & 380 & 318 & 1217 & 1012 & 5,9 \\
\hline 27 & 750 & 597 & 305 & 318 & 1378 & 1098 & 9 \\
\hline 28 & 800 & 621 & 301 & 297 & 1571 & 1178 & 0 \\
\hline
\end{tabular}

$$
\begin{aligned}
P_{T} & =P_{F T}+P_{T T} \\
& =432+32=464 \mathrm{Watt}
\end{aligned}
$$

The installed power needed lighting of a laboratory is $464 \mathrm{~W}$. As the number of lamps and kinds at both laboratories are the same, total power supplied by hybrid system is:

$$
\text { Total Power }=464 \times 2=928 \mathrm{~W}
$$

How long accumulators can supply the lamp groups is found with the formula below (5):

$$
\text { Time }=\frac{\text { Total Consumed Energy }}{\text { Total Power }}
$$




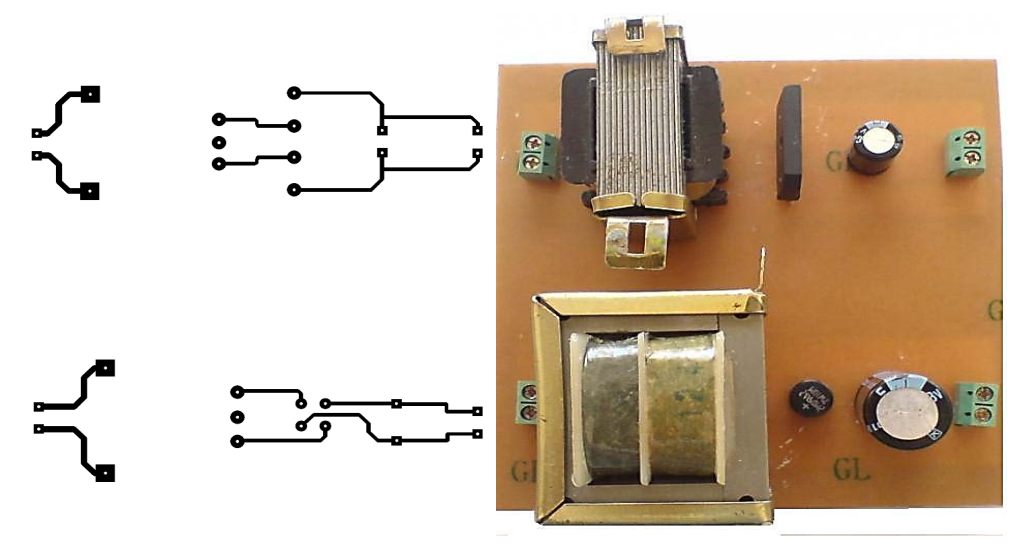

Figure 12. Printed circuit of supply circuit.

Total power of lamp groups needed for lighting of both laboratories is $928 \mathrm{~W}$. While making of accumulator calculation, by taking into consideration that $20 \%$ of accumulator capacity must be kept as safety charge, $80 \%$ capacity of installed $300 \mathrm{Ah}$ accumulator group is found.

$$
C_{k}=300 \times 0.8=240 \mathrm{Ah}
$$

It is not correct to select an accumulator according to this obtained result. Because it is necessary to add lost energy that occurred in accumulator and installation. If it is considered that the lost energy is $10 \%$ in accumulator and $2 \%$ in installation, the correct accumulator capacity is:

$$
C_{k}=240 \times 0.9 \times 0.98=211.68 \mathrm{Ah}
$$

Finally, multiplication of accumulator capacity by system voltage will give total energy to be consumed.

$$
\begin{aligned}
\text { Total consumed energy } & =C_{k} \times \text { Voltage } \\
& =211.68 \times 24=5080.32 \mathrm{Ah}
\end{aligned}
$$

Here, if the value found with Equation (8) is written in its place in Equation (5), it is determined that accumulator groups will supply lamp groups for about 5.5 - 6 hours in case all lamp groups are activated.

$$
\begin{aligned}
& \text { Time }=\frac{\text { Total Consumed Energy }}{\text { Total Power }} \\
& \text { Time }=\frac{5080.32}{928}=5.46 \text { saat } \cong 5.5-6 \text { saat }
\end{aligned}
$$

\section{Findings}

In order to be able to make efficiency analysis of the installed load control system, electric energy value consumed in general lighting according to weekly course hours made at two laboratories for both situations when load control system is active and load control system is not active must be known. Then, in what extent electric energy generated by hybrid power generation system meets electric energy consumed for general lighting of laboratories is determined. According to the obtained data, with using of installed load control system, how much saving has been made is determined. Course days and hours of Electric Laboratory- 1 and Electric Laboratory- 2 are given in Table 3. By taking into consideration the course hours and days, separate measurements were made for 12 months and measurements were presented in tables in details by months.

\subsection{Total Current Consumptions for States When Load Control System Is Active and Passive}

In situation the load control system was passive, a counter was connected to inlet of lighting line of Electric Laboratory- 1 to determine total consumed electric energy according to course days and by turning on all lighting elements, total energy consumed by Electric Laboratory-1 per hour was found as $588 \mathrm{Wh}$. As both laboratories are symmetrical to each other, no separate measurement was made for Electric Labarotroy-2. As it can be understood 
Table 3. Chart showing laboratory course days and course hours (1 week).

\begin{tabular}{ccc}
\hline & Electrical-1 Lab. & Electrical-2 Lab. \\
\hline Monday & Control Technics Lab. (3 hour) & Energy Systems Lab. (2 hours) \\
Tuesday & - & Electric Machines Lab. (2 hours) \\
Wednesday & - & Control Systems Lab. (2 hours) \\
Thursday & - & - \\
Friday & - & - \\
\hline
\end{tabular}

from Chart 4.2, when load control system is passive, while daily consumed minimum energy is $1.176 \mathrm{kWh}$, daily consumed maximum energy is $2.940 \mathrm{kWh}$. Weekly consumed energy is $5.292 \mathrm{kWh}$. Four times of determined weekly consumption value will give monthly total consumption energy for a situation load control system does not exist. January month total consumption $=5292 \times 4=21,168 \mathrm{kWh}$.

In situation the load control system was active, a counter was connected to inlet of lighting line of Electric Laboratory- 1 to determine total consumed electric energy according to course days but this time, armature groups to be activated will be determined with load control circuit with PIC depending on sunshine coming from outside. Load control circuit with PIC was only installed at Electric Laboratory-1 as Electric Laboratory-1 and Electric Laboratory-2 are symmetric to each other, installation of load control system is costly and there is time restriction. For these reasons, measurements were realized at Electric Laboratory-1 by taking into consideration course hours of Electric Laboratory-1 and Electric Laboratory-2. Accordingly, in situation the load control circuit with PIC was active, measurements were made in January according to course hours and days of laboratories and accordingly, total energy consumed in 1 week is given in Table 4.

\subsection{Energy Generation Values of Wind-Solar Hybrid Power Generation System by Months}

Data record was made regularly throughout one year by means of charge regulator in the battery-aided wind-solar hybrid power generation system. In data records, electric energy values generated by wind panel and wind turbine and stored by battery groups were recorded in $10 \mathrm{sec}$ intervals by means of a computer connected to charge regulator. The power generation graphics of wind turbine, solar panels and battery groups by months are given in Figure 13 and Figure 14 respectively.

When one-year generation and consumption data are examined, it is seen that energy obtained from solar panels are much higher than energy from wind turbines. The lowest energy generation in is in June month because of malfunction occurred in hybrid power generation system in that month and no data could be obtained for 7 days.

\section{Comparative Analysis of Wind-Solar Hybrid Power Generation System and Energy Consumption Values}

Electric energy generated by wind turbine and solar panels are stored in battery groups. Invertor battery connected to battery groups inverts the stored DC energy to AC energy when armature groups demand energy and supply energy to armature groups as stated before. In this context, electric energy to be used is the energy stored in battery groups. Whether the energy stored in batteries meet total consumption according to situations the load control does not exist (manual control) and load control exists (automatic control) are given in Figure 15.

Comparative analysis of generated electric energy and consumed electric energy is given in Figure 15. In this comparative analysis, whether energy generated from hybrid power generation system meets demanded electric energy in manual control position and automatic control position and besides, saving values obtained with automatic control designed for load control by using PIC 16F877 are examined by months in detail.

As it can be understood from Table 5, electric energy generated from wind-solar hybrid power generation system meets needed electric energy both in manual control consumption situation and automatic control consumption situation. Besides, if manual control method will be used, 313,279 kWh generation surplus electric energy and if automatic control method will be used, 365,359 kWh generation surplus electric energy is stored in battery groups. For this reason, in the event that necessary agreements are made and technical infrastructure are established, generation surplus electric energy can be sold to "Turkish Electricity Distribution Company (TEDAS)" 
Table 4. Chart showing energy consumed totally according laboratory course days in case the load control system is not active (1 week).

\begin{tabular}{|c|c|c|c|c|c|c|}
\hline \multirow{2}{*}{ Days } & \multicolumn{3}{|c|}{$\begin{array}{l}\text { Load Control System is passive } \\
\text { Total electrical consumptions }\end{array}$} & \multicolumn{3}{|c|}{$\begin{array}{l}\text { Load Control System is active } \\
\text { Total electrical consumptions }\end{array}$} \\
\hline & Electrical-1 Lab. & Electrical-2 Lab. & Daily Total & Electrical-1 Lab. & Electrical-2 Lab. & Daily Total \\
\hline Monday & $1764 \mathrm{Wh}$ & $1176 \mathrm{Wh}$ & $2940 \mathrm{Wh}$ & $1550 \mathrm{Wh}$ & $1135 \mathrm{Wh}$ & $2685 \mathrm{Wh}$ \\
\hline Tuesday & 0 & $1176 \mathrm{Wh}$ & $1176 \mathrm{Wh}$ & 0 & $1176 \mathrm{Wh}$ & $1176 \mathrm{Wh}$ \\
\hline Wednesday & 0 & $1176 \mathrm{Wh}$ & $1176 \mathrm{Wh}$ & 0 & $1176 \mathrm{Wh}$ & $1176 \mathrm{Wh}$ \\
\hline Thursday & 0 & 0 & 0 & 0 & 0 & 0 \\
\hline Friday & 0 & 0 & 0 & 0 & 0 & 0 \\
\hline TOTAL & $1764 \mathrm{Wh}$ & $3528 \mathrm{Wh}$ & & $1550 \mathrm{Wh}$ & $3487 \mathrm{Wh}$ & \\
\hline Weekly Total & & $5292 \mathrm{Wh}$ & & & $5037 \mathrm{Wh}$ & \\
\hline
\end{tabular}
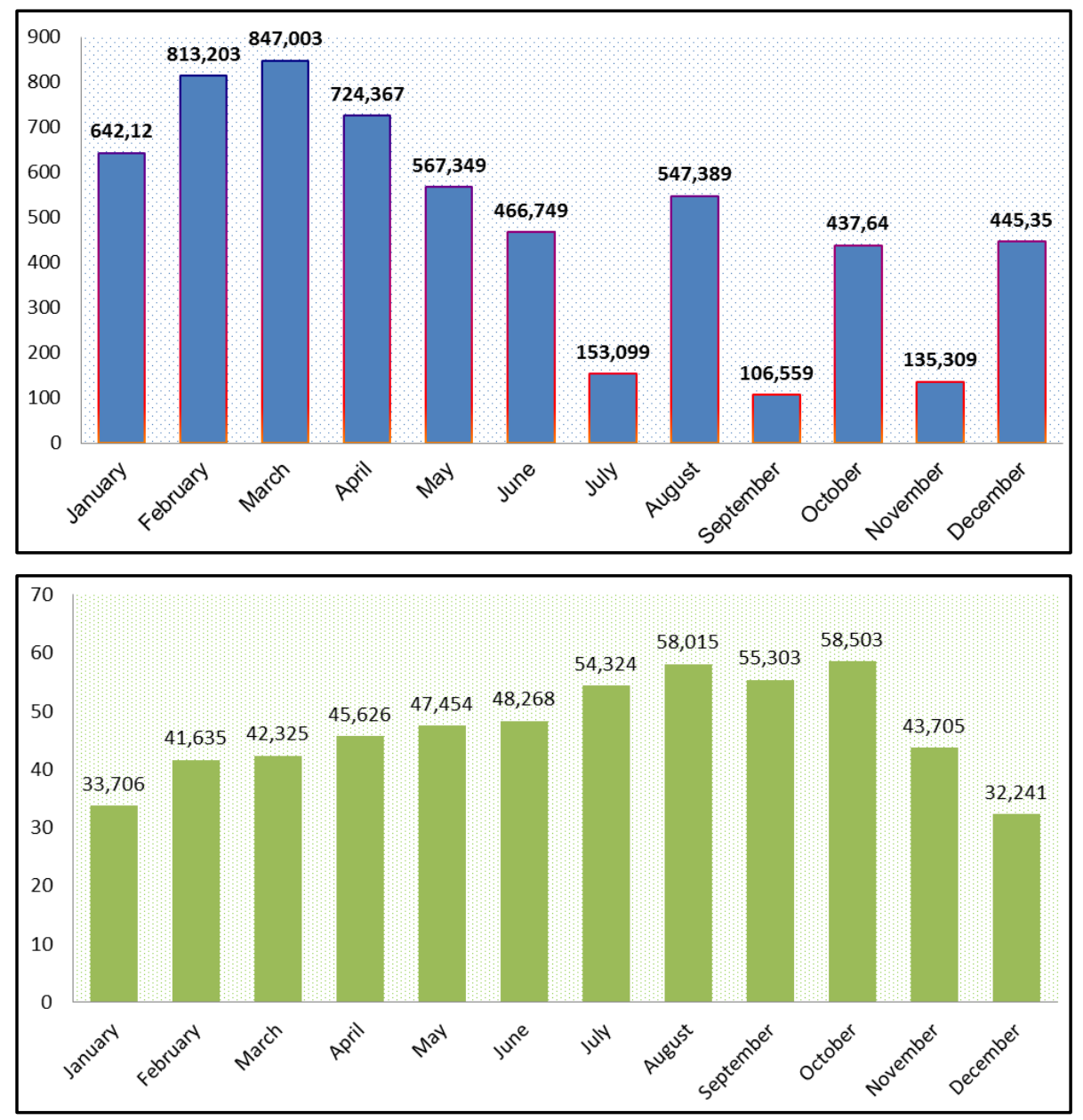

Figure 13. Energy generated by wind turbine and solar panel by months (Wh).

and amortization period of hybrid power generation system can be shortened. In the event that manual control system is used in lighting of laboratory, annual consumption value will be 254,016 kWh and in case of automatic control system, it will be 201,936 kWh. These values indicate that using of designed automatic load control system will ensure annual $52.26 \mathrm{kWh}$ energy saving. 


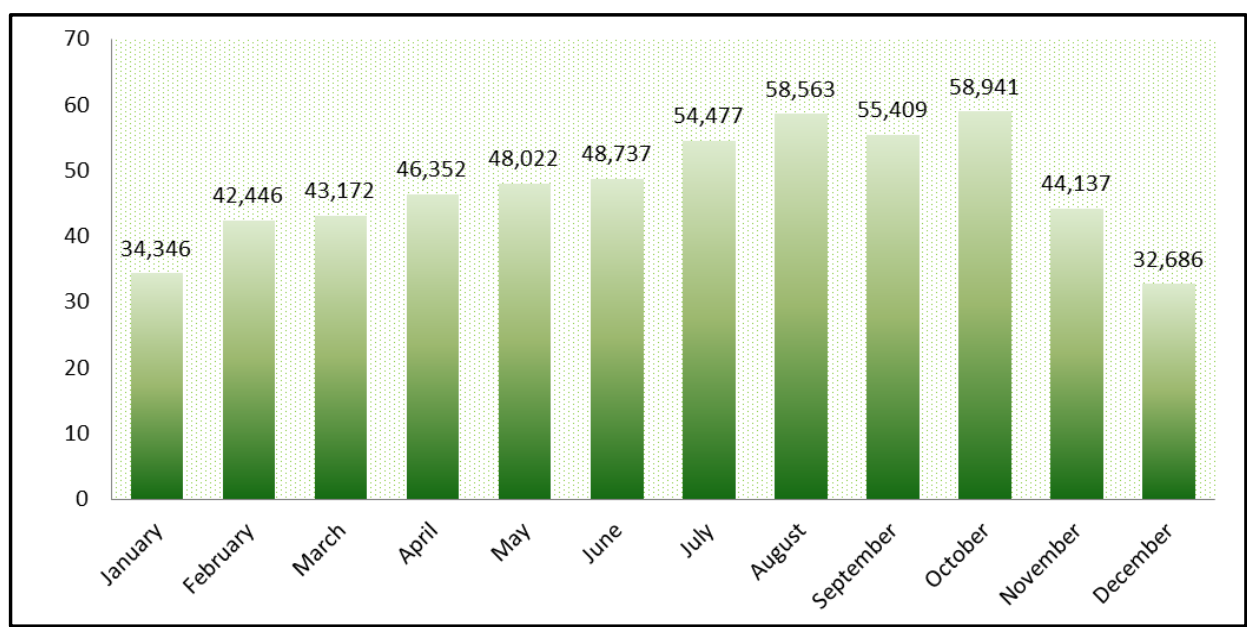

Figure 14. Energy stored by battery group by months (kWh).

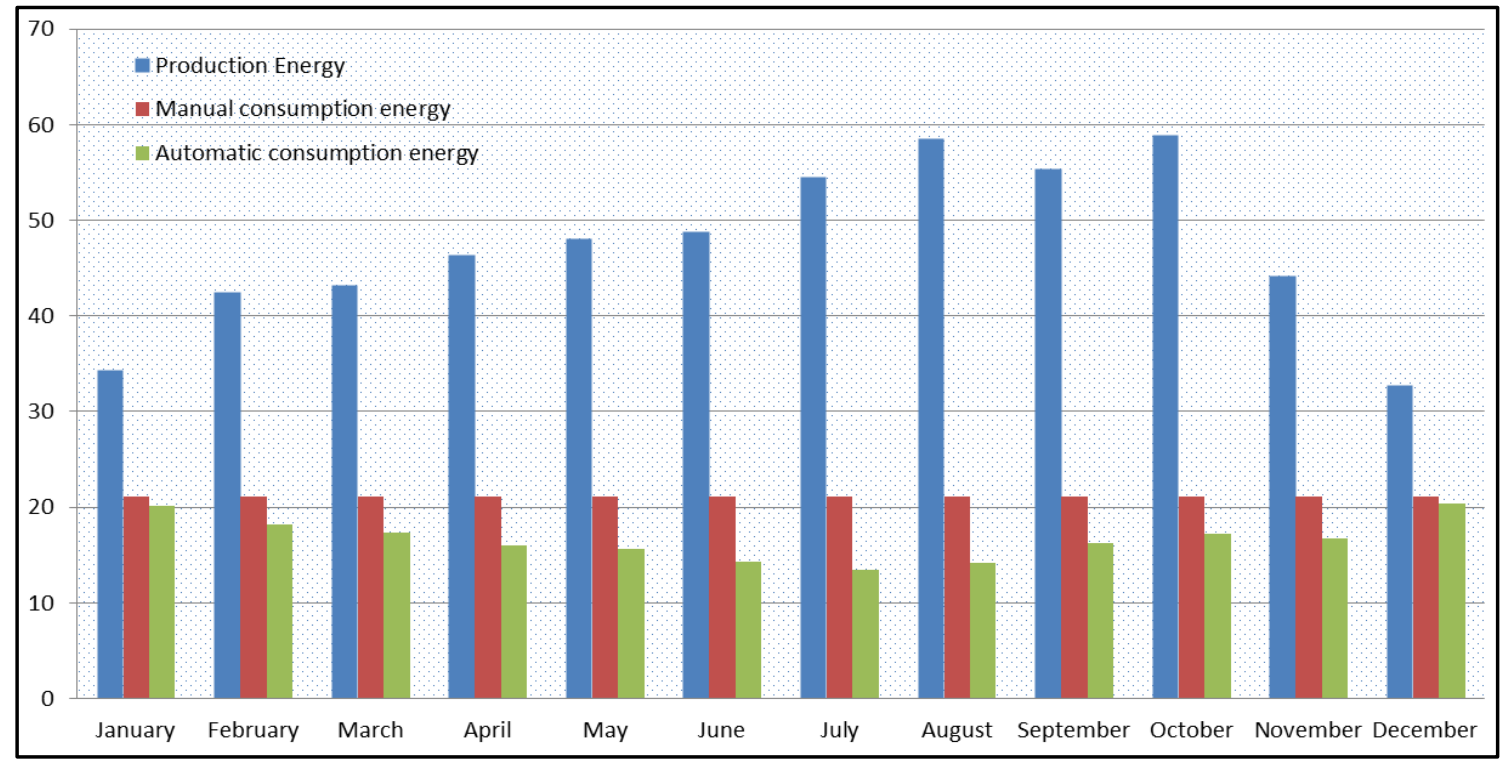

Figure 15. Energy generated totally and consumed totally by months.

\section{Conclusions}

Hybrid power generation system which is controlled by microcontroller was installed for different laboratories in Afyon Kocatepe University. The purpose of this study is to realize energy saving by using above stated hybrid system. The electric energy generated by photovoltaic panels is affected by sunshine duration. Solar data were obtained by measuring in the laboratories. As a result of the measurements made according to weekly curriculum of Electric Laboratory-1 and Electric Laboratory-2 (course hours of Electric Laboratory-1 and Electric Laboratory-2 between dates of 3-9 June 2012 were taken into consideration), when one-year total consumption values are examined, it is determined that consumption for former switched (manual control) system is $254.016 \mathrm{kWh}$ and consumption for PIC controlled (automatic control) system is $201.936 \mathrm{kWh}$. These values indicate that using of designed automatic load control system will provide annual $52.26 \mathrm{kWh}$ energy saving. This value corresponds to $20.6 \%$ energy saving in percentage.

Capacity of accumulator group the electric energy obtained from hybrid wind-solar power generation system is stored by being inverted to chemical energy is $300 \mathrm{Ah}$. As that capacity value was not used completely during measurements, grid support was not needed. In other words, energy used in lighting system was completely generated by hybrid wind-solar power generation system. 
Table 5. Comparison of generation and consumption values.

\begin{tabular}{|c|c|c|c|c|c|c|}
\hline Months & $\begin{array}{l}\text { Production (P) } \\
\text { (kWh) }\end{array}$ & $\begin{array}{c}\text { Manual Control } \\
\text { Consumptions }\left(\mathrm{T}_{\mathrm{mk}}\right)(\mathrm{kWh})\end{array}$ & $\begin{array}{c}\text { Automatic Control } \\
\text { Consumptions }\left(\mathrm{C}_{\mathrm{ok}}\right)(\mathrm{kWh})\end{array}$ & $\begin{array}{l}\mathrm{C}_{\mathrm{mk}}-\mathrm{C}_{\mathrm{ok}} \\
(\mathbf{k W h})\end{array}$ & $\begin{array}{l}\text { G-C } \mathrm{Cmk}_{\mathrm{mk}} \\
(\mathrm{kWh})\end{array}$ & $\begin{array}{l}\text { G-C }{ }_{\text {ok }} \\
(\mathrm{kWh})\end{array}$ \\
\hline January & 34,348 & 21,168 & 20,148 & 1,200 & 13,180 & 14,200 \\
\hline February & 42,449 & 21,168 & 18,184 & 2,984 & 21,281 & 24,265 \\
\hline March & 43,172 & 21,168 & 17,364 & 3,804 & 22,004 & 25,808 \\
\hline April & 46,353 & 21,168 & 16,064 & 5,104 & 25,185 & 30,289 \\
\hline May & 48,022 & 21,168 & 15,668 & 5,500 & 26,854 & 32,354 \\
\hline June & 48,737 & 21,168 & 14,288 & 6,880 & 27,569 & 34,449 \\
\hline July & 54,478 & 21,168 & 13,468 & 7,700 & 33,310 & 41,010 \\
\hline August & 58,563 & 21,168 & 14,228 & 6,940 & 37,395 & 44,335 \\
\hline September & 55,409 & 21,168 & 16,284 & 4,884 & 34,241 & 39,125 \\
\hline October & 58,941 & 21,168 & 17,204 & 3,964 & 37,773 & 41,737 \\
\hline November & 44,137 & 21,168 & 18,700 & 2,468 & 22,969 & 25,437 \\
\hline December & 32,686 & 21,168 & 20,336 & 0,832 & 11,518 & 12,350 \\
\hline Total & 567,295 & 254,016 & 201,936 & 52,260 & 313,279 & 365,359 \\
\hline
\end{tabular}

Consequently, it is put forth that with using of load control system for lighting of laboratory, more effective using of electric energy obtained from hybrid wind-solar power generation system can be provided. Lighting system was operated depended on exterior lighting level in a manner providing 300 lux lighting intensity on working plane. Besides, by activating armature groups in separate quartet groups (four each) instead of twelve groups, occurrence of unnecessary light flux was prevented. When light intensity increased above 300 lux value or decreased below that value on working plane, the lux sensor activated or deactivated armatures according to light intensity coming from outside and so, natural lighting was benefited from in the highest rate.

The most frequently applied method in improvement of efficiency obtained from solar panels used in hybrid wind-solar power generation systems is the solar tracking system. Because, the highest efficiency from solar panels is provided when solar beams are fallen vertically on the panel surface. In increasing of efficiency of wind turbine in the hybrid system, number of poles, especially in selection of turbine, must be kept in maximum number as much as possible. Because, wind turbine starts electric generation in low wind speeds as much as the number of pole increases. Besides, if the charge regulator to be selected has a low voltage feature, energy generation efficiency in percentage of about $20 \%$ will be ensured.

With the load control system, saving in energy consumption could be obtained in some extent. In order to be able to increase energy saving and decrease consumed energy, either more efficient lighting elements must be preferred during installation phase or lighting elements that enable dimmer lighting control must be preferred.

\section{Acknowledgements}

This research has been supported by grant number 10-TEF-05 from Afyon Kocatepe University Scientific Research Projects Coordination Unit.

\section{References}

[1] Dursun, B. (2013) Energy Sector in Turkey Current Status and Future Project. Kırklareli Üniversitesi Ekonomik ve Sosyal Araştırmalar Merkezi Araştırma Raporu, 1, 1-14.

[2] Özkop, E., Altaş, İ.H. and Sharaf, A.M. (2008) Rüzgar/Fotovoltaik Karma Sisteminden Beslenen DA Yükler için Üç Çevrim Destekli PID Denetleyici. ELECO 2008 Elektrik-Elektronik-Bilgisayar Mühendisliği Sempozyumu, Bursa, 2630 November 2008.

[3] Bagul, A.D., Salameh, Z.M. and Borowy, B. (1996) Sizing of a Stand-Alone Hybrid Wind-Photovoltaic System Using 
a Three-Event Probability Density Approximation. Solar Energy, 56, 323-335. http://dx.doi.org/10.1016/0038-092X(95)00116-9

[4] Dursun, B. and Gokcol, C. (2011) The Role of Hydroelectric Power and Contribution of Small Hydropower Plants for Sustainable Development in Turkey. Renewable Energy, 36, 1227-1235. http://dx.doi.org/10.1016/j.renene.2010.10.001

[5] Wang, L. and Singh, C. (2006) PSO-Based Multi-Disciplinary Design of a Hybrid Power Generation System with Statistical Models of Wind Speed and Solar Insolation. International Power Electronics, Drives and Energy Systems, PEDES’06, 12-15 December 2006.

[6] Kellogg, W.D., Nehrir, M.H., Venkataramanan, G. and Gerez, V. (1998) Generation Unit Sizing Cost Analysis for Stand-Alone Wind, Photovoltaic, and Hybrid Wind/PV Systems. IEEE Transaction on Energy Conversion, 13, 70-75. http://dx.doi.org/10.1109/60.658206

[7] Engin, M. (2010) Bornova Için Güneş-Rüzgâr Hibrid Enerji Üretim Sistemi Tasarımı. C.B.Ü. Soma Meslek Yüksekokulu Teknik Bilimler Dergisi, 2, 11-20.

[8] Dursun, B., Gokcol, C., Umut, I., Ucar, E. and Kocabey, S. (2012) Techno-Economic Evaluation of a Hybrid PV-Wind Power Generation System. International Journal of Green Energy, 10, 117-136. http://dx.doi.org/10.1080/15435075.2011.641192

[9] Dursun, B. and Gokcol, C. (2012) Economic Analysis of a Wind-Battery Hybrid System: An Application for a House in Gebze, Turkey, with Moderate Wind Energy Potential. Turkish Journal of Electrical Engineering \& Computer Sciences, 20, 319-333.

[10] Köse, G. (2010) Hibrit (Güneş + Rüzgar) Enerji Sisteminden Elektrik Üretimi: Kütahya Örneği. Yüksek Lisans Tezi, Dumlupınar Üniversitesi, Fen Bilimleri Enstitüsü, Kütahya.

[11] Muralikrishna, M. and Lakshminarayana, V. (2008) Hybrid (Solar and Wind) Energy Systems for Rural Electrification. ARPN Journal of Engineering and Applied Sciences, 3, 50-58.

[12] Lu, L. (2004) Investigation on Characteristics and Application of Hybrid Solar-Wind Power Generation Systems. The Hong Kong Polytechnic University, Hong Kong. http://repository.lib.polyu.edu.hk/jspui/handle/10397/3409

[13] Gabriele, S.H. (1998) Optimization of Hybrid Energy Systems Sizing and Operation Control. Ph.D. Thesis, University of Kassel, Kassel. http://www.uni-kassel.de/upress/online/frei/978-3-933146-19-9.volltext.frei.pdf

[14] Gençoğlu, M.T. (2005) İç Aydınlatmada Enerji Tasarrufu. III. Ulusal Aydınlatma Sempozyumu, Ankara.

[15] Toylan, H. (2008) Laboratuar İç Aydınlatmasının PLC ve Bilgisayar Yardımı ile Kontrolü. Yüksek Lisans Tezi, Marmara Üniversitesi, Fen Bilimleri Enstitüsü, İstanbul.

[16] Sağlam, Ş. (2006) Şebeke Bağlantılı Fotovoltaik Aydınlatma Sisteminin Bulanık Mantık ile Kontrolü. Doktora, Marmara Üniversitesi, Fen Bilimleri Enstitüsü, İstanbul.

[17] http://www.solar-bazaar.com/menuis/VIND-TURBINE-EFS600-Manual.pdf 